\title{
ENVIRONMENTAL CONCERNS IN THE ACCELERATED MAHAWELI PROJECTT
}

\author{
D.M.S.H.K. Ranasinghe, \\ Department of Forestry and Environmental Science \\ University of Sri Jayewardenepura.
}

The Mahaweli Development Project is the largest single development programme undertaken by the Government of Sri Lanka. The Accelerated Programme which was completed in 5 years envisaged the construction of 4 major reservoirs with hydro-electricity plants, developed about 175,360 ha of lands in the downstream areas with irrigation facilities and established new settlements of about 74,253 families. New and improved cultivation resulted in the annual production of more than 600,000 tons of rice. The reservoirs increased the hydroelectric generating capacity by about 400 megawatts.

Among the impacts of the Upper Mahaweli Catchment which includes watersheds and subwatersheds of Kotmale Oyal. Maha Oya, Umat Oya, Beli-loul Oya is vital as the principle source of water for hydropower and irrigation projects. Among the threats to the environment. the premature silting up of a number of reservoirs especially Polgolla, Rantambe etc. can be noted. Deforestation for chena cultivation in the stecp slopes coupled with the high water lable prevalent in the area results in earthslips and landslides. Deforestation has also caused significant reduction in wildlife habitats in both upstream and downstream areas. A large number of animals and plants including endangered, threatened and endemic species had been reduced. Due to the use of high quantities of agrochemicals the agricultural return waters has caused cutrophication in reservoirs, tanks and other waterhodies impairing the effective funclioning of these entities and affecting the life forms in them.

Among the significant concerns in the downstream areas, rise in the watertable thus necessitating drainage, increased salinity in some areas, contamination of natural water ways due to high usage of agrochemicals in agricultural practices. increased encounters with pocketed wild animals calusing death and damages to property can be cited.

Among the social concerns of the settements, necessity of high inputs thus reducing the net income of the farmers, inability to manage holdings with family labour, inadequate supplies of irrigattion water, inadequate service facilities (Iransportation, schooling, health etc.). restricted/un employment of the second generation settlers, increased incidence of waler borne and vector borne diseases, teenage suicides can be mentioned.

Mitigalory measures which have already been laken by Mahaweli Authority 10 address these concerns have been stated along with some recommendations fort the future to achieve the objectives of the Mahatweli Programme on a environmentally sustainable manner.

Procededings of the Fourth Anmal Forestry and Environment Sympositum 1998 of the Department of Forestry and Enviromental Science. University of Sri Jayewardenepura, Sri Lanka 